\section{TERPENES}

BARK

TIMBER

PINE
EMISSIONS

WOOD

PULPWOOD

SPRUCE

Open access manuscript version of

Environmental Pollution 79 (1993) 215-218

doi:10.1016/0269-7491(93)90092-3

\title{
Monoterpenes emitted to air from industrial barking of Scandinavian conifers
}

Ann-Margret Strömvall and Göran Petersson

Comparable studies of terpene emissions were made for:

Kraft pulp mills

$\underline{\text { TMP and sulphite pulp mills }}$ 


\section{Monoterpenes Emitted to Air from Industrial Barking of Scandinavian Conifers.}

Ann-Margret Strömvall and Göran Petersson

Department of Chemical Environmental Science

Chalmers University of Technology

41296 Göteborg, Sweden 


\begin{abstract}
Monoterpenes released to air were determined during single-log barking of timber at a saw-mill and during tumble drum barking of pulpwood at a TMP mill. Characteristic roportions of fourteen compounds were assessed by adsorbent sampling and gas chromatography. For Scots pine (Pinus sylvestris), the bicyclic monoterpenes $\alpha$-pinene and 3-carene predominated. For Norway spruce (Picea abies), $\alpha$-pinene followed by $\beta$-pinene were the major components. The proportions of $\beta$-phellandrene and myrcene from spruce were remarkably high from barking compared to wood processing. Environmental aspects on the emissions are discussed.
\end{abstract}




\section{INTRODUCTION}

Cortical terpenes of conifers such as Norway spruce interact in a complex manner in the forest ecosystem with insects (Lindström et al., 1989) as well as fungi (Schuck and Schütt, 1975). Basically, terpenes are emitted from bark wounds as an integrated part of the defense mechanisms of the tree. Artificial barking therefore results in comparatively large monoterpene emissions to air. The monoterpenes are very reactive in air with short lifetimes (Atkinson et al., 1990) and give rise to a variety of photooxidants. Man-mediated emissions of monoterpenes are therefore of concern with respect to the phytotoxicity of many photooxidants. The present study of terpenes released during industrial barking was undertaken with these circumstances in mind.

In a previous study, monoterpenes from logging of Scots pine and Norway spruce were assessed (Strömvall and Petersson, 1991). Industrial emissions from wood of Norway spruce were studied for groundwood pulp production (Strömvall and Petersson, 1990). 


\section{EXPERIMENTAL}

\section{Barking facilities}

Timber barking was studied for a conventional Cambio machine of Swedish make. The saw-mill was the Anneberg plant south of Göteborg with an annual production of $50000 \mathrm{~m}^{3}$ of sawed timber. The machine is placed in a separate building where samples were taken. The logs pass the machine one at a time while the bark falls down on a transport band. Exclusively Scots pine or exclusively Norway spruce were processed in alternating campaigns of several days. The timber had been stored for less then two months after logging.

Pulpwood barking was studied for a tumble drum of the Finnish make Vaplan (30 $\mathrm{m}$ in length and $5 \mathrm{~m}$ in diameter). The pulp mill was Bravikens Pappersbruk near Norrköping on the Swedish east coast, producing 400000 tons per year of thermomechanical pulp. Samples were taken near the barking drum from which bark falls out through slits in the drum. The drum is placed inside a building where pulpwood is entered at one end and barked pulpwood is delivered to chipping at the other. The pulpwood barked originates exclusively from Norway spruce. The supply was a mixture of fresh pulpwood and pulpwood stored for a few mounths.

\section{Analytical technique}

Tenax adsorbent cartridges were used for taking samples of $\sim 100 \mathrm{ml}$ during 10-20 minutes. In the laboratory, the terpenes were thermally desorbed and analyzed by temperature-programmed $\left(2^{\circ} \mathrm{C} \mathrm{min}-1\right.$ from $\left.0^{\circ} \mathrm{C}\right)$ gas chromatography with flame ionization detection. The column was a fused silica capillary $(25 \mathrm{~m} \times 0.33 \mathrm{~mm}$ i.d.) with a cross-linked methylsilicone (BP-1, $0.5 \mu \mathrm{m})$ as the stationary phase. Further analytical data were given in a recent study of monoterpenes from logging operations (Strömvall and Petersson, 1991). 


\section{RESULTS}

Conclusive data for Scots pine and Norway spruce are given in Table 1, expressed as the percentual composition of monoterpenes in terpene-polluted air.

The first two columns compare the barking of pine and spruce timber in the same machine, of the type normally used at saw-mills. The figures given are averages of several samples taken on one occasion for pine and on two occasions for spruce. The results for the simultaneously taken samples were very similar, and the differences between the two spruce sampling occasions were not significant.

For Scots pine, $\alpha$-pinene and 3-carene predominate with $\beta$-pinene as the only additional component constituting more than $2 \%$ of total monoterpenes. For Norway spruce, $\alpha$-pinene followed by $\beta$-pinene are the major species, with 3-carene, $\beta$-phellandrene, and limonene following next, below the $10 \%$ level. Among the minor monoterpenes, the proportions of tricyclene, camphene, and myrcene are higher for spruce than for pine, whereas the reverse is true for $\gamma$-terpinene and terpinolene.

The third column of Table 1 gives data from the barking of Norway spruce pulpwood in a tumble drum of the type used at large pulp industries. The chromatogram reproduced (Fig. 1) illustrates the composition and the analytical separation of the monoterpenes. The results differ from those for spruce timber barking by a lower proportion of $\alpha$-pinene and higher proportions of myrcene, $\beta$-phellandrene, and limonene.

The late-eluting sesquiterpene hydrocarbons from the barking of spruce pulpwood were found to constitute $\sim 0.5 \%$ of the total monoterpenes. The major component, longifolene, amounted to $\sim 30 \%$ of the total sesquiterpenes. 


\section{TABLE 1}

Percentual composition of monoterpenes emitted to air during industrial barking and related operations.

\begin{tabular}{|c|c|c|c|c|c|}
\hline & $\begin{array}{c}\text { Scots pine } \\
\text { Timber } \\
\text { Dry log barking }\end{array}$ & $\begin{array}{l}\text { Norway spruce } \\
\text { Timber } \\
\text { Dry log barkinga }\end{array}$ & $\begin{array}{l}\text { Norway spruce } \\
\text { Pulp wood } \\
\text { Dry dnum barkingb }\end{array}$ & $\begin{array}{l}\text { Norway spruce } \\
\text { Wood chips } \\
\text { TMP Refiningb }\end{array}$ & $\begin{array}{c}\text { Norway spruce } \\
\text { Logging } \\
\text { Harvesterc }\end{array}$ \\
\hline tricyclene & 0.1 & 0.3 & 0.3 & 0.4 & 0.7 \\
\hline$\alpha$-thujene & 0.1 & 0.1 & 0.1 & 0.1 & 0.1 \\
\hline$\alpha$-pinene & 44 & 51 & 44 & 58 & 38 \\
\hline camphene & 0.7 & 2.2 & 2.3 & 1.7 & 5.6 \\
\hline$\beta$-pinene & 6.3 & 29 & 29 & 26 & 28 \\
\hline myrcene & 1.1 & 2.0 & 4.7 & 1.0 & 6.0 \\
\hline$\alpha$-phellandrene & 0.1 & 0.1 & 0.1 & 0.1 & 0.2 \\
\hline 3-carene & 43 & 5.2 & 5.3 & 3.5 & 4.6 \\
\hline$\alpha$-terpinene & 0.1 & 0.1 & 0.1 & 0.1 & 0.2 \\
\hline$\beta$-phellandrene & 0.9 & 5.2 & 9.0 & 3.0 & 8.3 \\
\hline limonene & 0.9 & 3.5 & 4.9 & 5.1 & 8.0 \\
\hline$\gamma$-terpinene & 0.3 & 0.1 & 0.1 & 0.1 & 0.2 \\
\hline terpinolene & 1.6 & 0.3 & 0.4 & 0.3 & 0.4 \\
\hline$p$-cymene & 0.7 & 1.0 & 0.5 & 0.8 & 0.5 \\
\hline
\end{tabular}

a Saw-mill, Anneberg, 5/30/91 (4 pine samples), 6/4/91(2 spruce samples), and 6/6/91 (4 spruce samples).

b Pulp mill, Bravikens Pappersbruk, 6/19/91 (2 samples) and 3/14/91 (refiner steam passed through chip feed).

c Strơmvall and Petersson, 1991. 


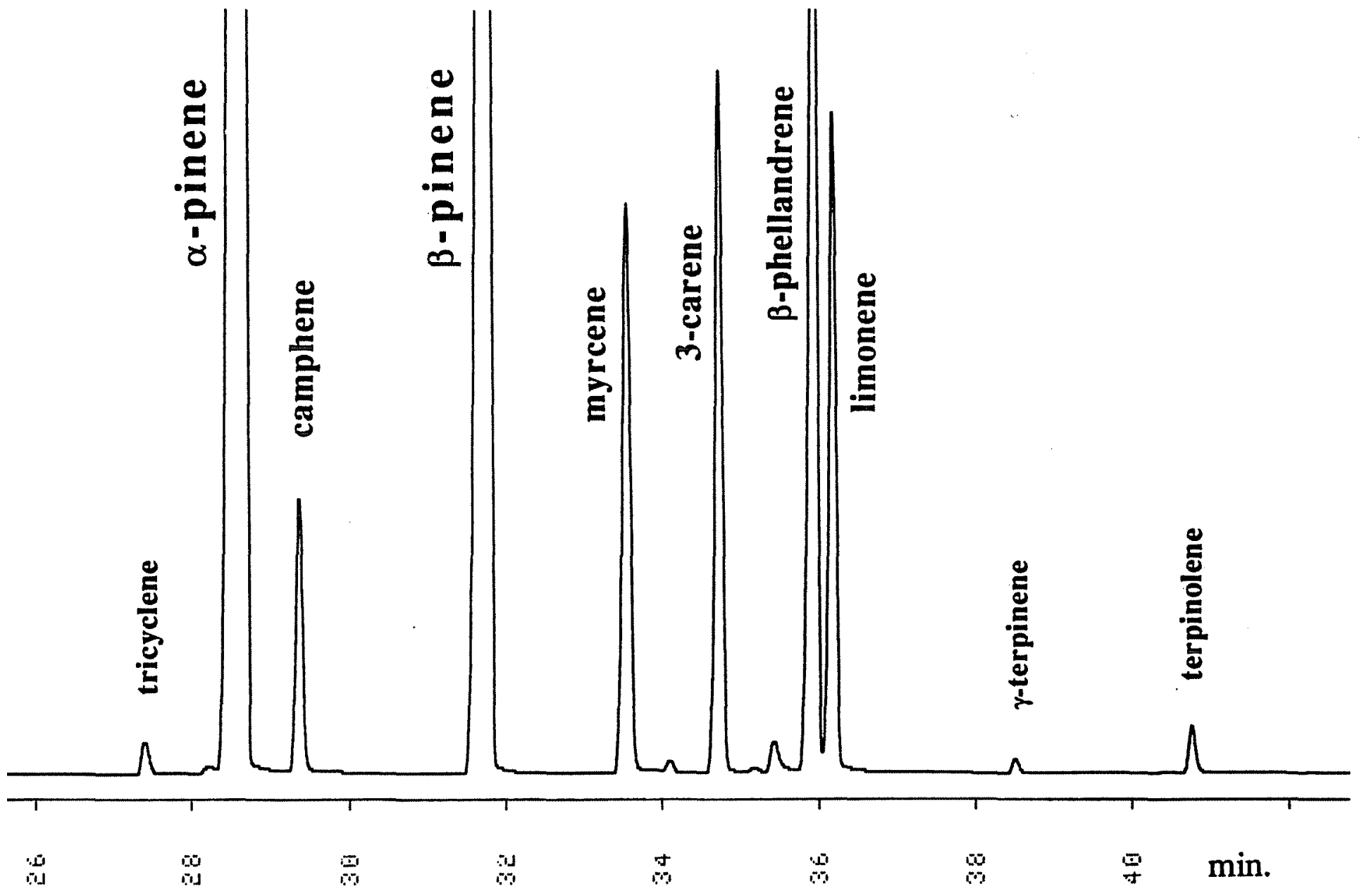

Fig. 1. Gas chromatographic assessment of Norway spruce monoterpenes emitted to air from dry drum barking of pulpwood (Bravikens Pappersbruk $6 / 19 / 91)$. 


\section{DISCUSSION}

\section{Terpenes from bark and wood}

The terpenes emitted during barking originate partly from the bark and partly from the more or less wounded outer sapwood. The fourth column of Table 1 gives data reflecting the average monoterpene content of bark-free spruce pulpwood. Essentially the same composition was observed in the emissions from groundwood pulp production from Norway spruce (Strömvall and Petersson, 1990). Compared to barking, the proportion of $\alpha$-pinene is higher from wood. This is partly explained by the distinctly higher content of $\alpha$-pinene in heartwood compared to sapwood for Norway spruce (Schuck and Schütt, 1975). The most characteristic difference, however, is the several times higher proportion of myrcene and $\beta$-phellandrene from barking compared to wood.

For spruce timber barking, the differences in composition compared to wood are qualitatively the same but not as large as for pulpwood barking. This may be explained by a larger contribution of wood monoterpenes from single-log barking, which is effected by rotating tools pressed towards the log. In the drum, bark may be removed with less wood wounds by the tumbling of the pulpwood logs against each other. The proportion of bark compared to wood is also smaller in timber because of the larger diameter of the logs. The results correspond to an average of a large number of trees, thus eliminating differences between individuals. These may be significant as indicated by studies of the oleoresin from young shoots of German clones of Norway spruce (Esteban et al., 1977).

The terpenes from barking might be expected to have about the same composition as the terpenes from cortical oleoresin exuded from bark wounds during logging. The last column of Table 1 gives the monoterpene composition reported for harvester logging of Norway spruce (Strömvall and Petersson, 1991). The high proportion of $\beta$-phellandrene from logging is similar to that from barking and indicates a large contribution from cortical oleoresin. Supporting evidence is given by the low proportion of $\beta$-phellandrene not only in the wood but also in the needles of Norway spruce (Jüttner, 1988). The major hydrocarbon monoterpenes in the needles are camphene, myrcene, limonene and $\alpha$-pinene. Young twig tissues of buds, bark and wood contain high proportions of myrcene and $\beta$-pinene (Bufler et al., 1990). Consequently, the proportions of the monoterpenes released during logging indicate that they originate to a large extent from the stem. Several of the terpenes released from barking and logging were reported in similar proportions in an early comprehensive study of the oleoresin from fresh wounds in trunks of Norway spruce (Kimland and Norin, 1972). In extracts of stem bark of Norway spruce, a large number of volatile components including terpenes have been identified (Heemann and Francke, 1977). 
For Scots pine, the observed monoterpene composition from timber barking is very similar to that reported from harvester logging (Strömvall and Petersson, 1991). Except for a higher proportion of 3-carene from barking, the composition is also similar to that observed for monoterpenes released from wood of Scots pine (Flodin and Andersson, 1977). The cortical oleoresin of young shoots of Swedish Scots pine is normally very rich in 3-carene, although the content is very variable between regions (Yazdani and Nilsson, 1986) and varieties (Thorin and Nommik, 1974). The monoterpene composition of Scots pine wood from different parts of Europe is also remarkably variable (Hafizoglu, 1983). It is concluded that the results given for barking of Norway spruce are more widely valid than those for barking of Scots pine.

\section{Environmental aspects}

Barked timber, mainly from pine and spruce, is sawed at 2000 Swedish saw-mills with an average annual production of $5000 \mathrm{~m}^{3}$. The terpenes released during barking as well as those from sawing and sawed products are emitted to air. The terpenes are mixed with nitrogen oxides from heat supply units to give photochemically reactive emission plumes. The Swedish environmental authorities estimate the total terpene emissions from saw-mills to 25000 tons per year.

Approximately 30 million $\mathrm{m}^{3}$ of barked pulpwood is processed annually in the Swedish pulp mills. Almost 15000 tons of turpentine is recovered, mainly from the digesters of the large kraft pulp mills. These mills process mainly the terpene-rich wood of Scots pine, mixed with wood from spruce and birch. Several large mills, notably those producing mechanical and thermomechanical pulp, process exclusively Norway spruce. Throughout, the terpenes from pulpwood barking are emitted to air, normally close to other process emissions. At the kraft and sulphite pulp industries, the terpene emissions are mixed with large emissions of both sulphur dioxide and nitrogen oxides. The mechanical pulp industries coemit considerable amounts of nitrogen oxides. Emission plumes of increased toxicity may also arise from interactions with traffic emissions (Strömvall and Petersson, 1990).

Environmental demands concerning terpene emissions to air from barking are likely to be based on the need for tackling the phototoxidant problem. The increased content of the very reactive (Atkinson et al., 1990) myrcene renders spruce barking emissions even more photochemically reactive than terpenes from wood processing. Unfortunately, turpentine recovery or incineration of emitted terpenes may be more difficult to realize for barking than for pulpwood processing. A means of avoiding detrimental interactions with other process emissions is to locate the barking facilities far from the industry. Photooxidant 
formation can also be diminished by avoiding barking during the anticyclonic spring and summer periods favouring photochemical activity. 


\section{REFERENCES}

Atkinson, R., Hasegawa, D. \& Aschmann, S.M. (1990). Rate constants for the gas-phase reactions of $\mathrm{O}_{3}$ with a series of monoterpenes and related compounds at $296^{\circ} \mathrm{K}$. Int. J. Chem. Kinet., 22, 871-887.

Bufler, U., Seufert, G. \& Jüttner, F. (1990). Monoterpene patterns of different tissues and plant parts of Norway spruce (Picea Abies L. Karst.). Environ. Pollut., 68, 367-375.

Esteban, I., Bergmann, F., Gregorius, H.R. \& Huhtinen, O. (1977).

Composition and genetics of monoterpenes from cortical oleoresin of Norway spruce and their significance for clone identification. Silvae. Genet., 25, 59-66.

Flodin, K. \& Andersson, J. (1977). Studies on volatile compounds from Pinus silvestris and their effect on wood-decomposing fungi. I. Identification of volatile compounds from fresh and heat-dried wood. Eur. J. For. Pathol., 7, 282-287.

Hafizoglu, H. (1983). Wood extractives of Pinus sylvestris L., Pinus nigra Arn. and Pinus brutia Ten. with special reference to nonpolar compounds.

Holzforschung, 37, 321-325.

Heemann, V. \& Francke, W. (1977). Gaschromatographisch-massenspektrometrische Untersuchungen der flüchtigen Rindeninhaltsstoffe von Picea abies (L.) Karst. Planta Medica, 32, 342-346.

Jüttner, F. (1988). Changes of monoterpene concentrations in needles of pollution-injured Picea abies exhibiting montane yellowing. Physiologia Plantarum, 72, 48-56.

Kimland B. \& Norin T. (1972). Wood extractives of Common Spruce, Picea abies (L.) Karst. Sven. Papperstidn., 75, 403-409.

Lindström, M., Norin, T., Birgersson, G. \& Schlyter, F. (1989). Variation of enantiomeric composition of $\alpha$-pinene in Norway spruce, Picea abies, and its influence on production of verbenol isomers by Ips typographus in the field. J. Chem. Ecol., 15, 541-548.

Schuck, H.J. \& Schütt, P. (1975). Die Verteilung flüchtiger Terpene im Fichtenstamm und ihre Bedeutung für die Ausbreitungsresistenz gegenüber Fomes annosus. Biochem. Physiol. Pflanzen, 167, 65-77.

Strömvall, A.-M. \& Petersson, G. (1990). Ambient monoterpenes from stone groundwood pulp production. Holzforschung, 44, 449-452.

Strömvall, A.-M. \& Petersson, G. (1991). Conifer monoterpenes emitted to air by logging operations. Scand J. For. Res., 6, 253-258.

Thorin, J. \& Nommick, H. (1974). Monoterpene composition of cortical oleoresin from different clones of Pinus sylvestris. Phytochemistry, 13, 1879-1881. 
Yazdani, R. \& Nilsson, J.-E. (1986). Cortical monoterpene variation in natural populations of Pinus sylvestris in Sweden. Scand. J. For Res., 1, 85-93. 